\title{
CHARACTERIZATION FOR PLANT HEIGHT AND FLOWERING DATE IN THE BIOLOGICAL SPECIES OAT ${ }^{1}$
}

\author{
RODRIGO RODRIGUES MATIELLO², MARIA JANE CRUZ MELLO SERENO ${ }^{3}$, JOSÉ FERNANDES BARBOSA NETO³, \\ FERNANDO IRAJÁ FÉLIX DE CARVALHO ${ }^{3}$, MARCELO TEIXEIRA PACHECO ${ }^{3}$, \\ DIEGO GIRARDI PEGORARO ${ }^{4}$ and IVONE TADERKA ${ }^{4}$
}

\begin{abstract}
The use of wild oat races in artificial hybridization with cultivated oat (Avena sativa $\mathrm{L}$.) has been used as a way of increasing the variability. This work aimed to identify the variability for plant height and flowering date of groups of cultivated oat genotypes, wild introductions of A. fatua L. and segregating populations of natural crosses between A. sativa and A. fatua. Wide genetic variability was observed for both traits in the groups and between them. The wild group of A. fatua L. showed high plants with early maturity, but in the segregating group there was reduced plant height and early maturity. The wild introductions of A. fatua L. studied in this work can be used in oat breeding programs to increase genetic variability by transferring specific characters into the cultivated germ plasm.
\end{abstract}

Index terms: plant breeding, Avena fatua, segregating populations.

CARACTERIZAÇÃO DA ESTATURA DE PLANTA E DATA DE FLORESCIMENTO NA ESPÉCIE BIOLÓGICA AVEIA

\begin{abstract}
RESUMO - A utilização de raças silvestres em hibridações com o grupo cultivado em aveia (Avena sativa L.) tem sido fonte de incremento da variabilidade genética. Desta forma, o presente trabalho foi desenvolvido com o objetivo de identificar e caracterizar a variabilidade genética dos caracteres morfofisiológicos estatura de planta e dias da emergência à floração em grupos de genótipos cultivados de aveia, introduções silvestres de $A$. fatua $\mathrm{L}$., e em populações segregantes dos cruzamentos naturais de $A$. sativa x A. fatua. Ampla variabilidade genética foi revelada para os caracteres avaliados tanto dentro como entre os grupos. O grupo silvestre A. fatua demonstrou plantas de elevada estatura e precoces. Foi possível encontrar populações segregantes de A. sativa x A. fatua com reduzida estatura e precocidade. As introduções silvestres de $A$. fatua avaliadas neste trabalho podem ser utilizadas em programas de melhoramento para incrementar a variabilidade genética, pela transferência de caracteres específicos para o germoplasma cultivado.
\end{abstract}

Termos para indexação: melhoramento vegetal, Avena fatua, populações segregantes.

${ }^{1}$ Accepted for publication on October 14, 1998.

2 Agronomist, M.Sc., Prof. Assistent, Dep. de Fitotecnia e Fitossanidade, Universidade Estadual de Ponta Grossa, Praça Santos Andrade, s/n, CEP 84010-790 Ponta Grossa, PR. E-mail: rrmatiel@uepg.br

${ }^{3}$ Agronomist, Dr., Dep. de Plantas de Lavoura, Faculdade de Agronomia da Universidade Federal do Rio Grande do Sul (UFRGS).

${ }^{4}$ Agronomist, Dep. de Plantas de Lavoura, Faculdade de Agronomia, UFRGS. Supported by CNPq.

\section{INTRODUCTION}

Avena fatua $\mathrm{L}$. is an hexaploid wild oat $(2 \mathrm{n}=6 \mathrm{x}=42)$ known as a noxious weedy plant from North America and other grain producing regions of the world. It is morphologically distinguished from cultivated oat by the presence of long geniculate awns and by seed shattering via abscission of individual florets. The genotypes frequently have colored dark seeds (gray, 
brown or red), and pubescence on the lemma rachilla and base of the seeds (Luby \& Stuthman, 1983). In Brazil, it has probably been introduced as impurity of cereal grains. In the South, it occurs spontaneously, as weed or in the edge of roads. Although hexaploidy in oat has been characterized by self-pollination, most researchers related natural hybrids between cultivated and silvester races (Derick, 1933). In the Southern Brazil, natural hybrids of A. sativa x A. sterilis $\mathrm{L}$. have been identified (Dillenburg, 1984).

The introduction of genes for low plant height on cultivated genotypes resulted in enhancement on grain yield, because lodging reduction and harvest index improvement. In oat, the effects of genes for low plant height have been limited because of the use of this cereal for many purposes (grain and forage) and most of all, cultivation on low fertility soils, which limits the height of the genotypes (Federizzi \& Qualset, 1989). Increasing in plant breeding efforts and environment adaptation led to development of genotypes with modified morphophysiological traits as low plant height, early maturity and high fertility (grains/panicle) which determined the increase in grain yield potential of new cultivars (Carvalho \& Federizzi, 1989).

Southern Brazil cultivation system consists of two crops sown each year in succession, in summer and winter; as a consequence the flowering date adjustment between crops is an important subject. The winter crop must be of early maturity, so the summer crop (soybean or maize) will not be delayed. Earliness in oat can be also used to avoid diseases such as crown and leaf rust, which cause great damages to grain yield (Bertagnolli,1992). Flowering date adequate to the production system induced an expressive grain yield progress of crops sown after the usual period. This earliness was reached with UFRGS-7 and UFRGS-8, the earliest commercial cultivars in 1987 (Carvalho \& Federizzi, 1989). For wheat, earliness and low plant height were determinant factors for grain yield enhancement, probably because the adjustment to light and temperature conditions (Briggle \& Vogel, 1968). Bertagnolli (1992) related genetic variability for earliness in oat germ plasm and suggested to transfer these genes into new genotypes. Besides, the existence of few genes for this trait and its genetic effect would favor selection for early genotypes in segregating populations.

Using oat wild races in breeding programs deserves a characterization of the genetic variability.

The purpose of this study was to identify and characterize genetic variability for plant height and flowering date of cultivated oat genotypes, introductions of $A$. fatua, and segregating populations of natural crosses between $A$. sativa and A. fatua.

\section{MATERIAL AND METHODS}

The experiment was conducted in 1994 and 1995 at UFRGS Research Station (EEA/UFRGS), in Eldorado do Sul, RS. The material was manually sown on rows $0.3 \mathrm{~m}$ apart and $3 \mathrm{~m}$ long with 10 seeds for each row.

Five cultivated genotypes (UFRGS-7, UFRGS-14, UFRGS-17, UFRGS-91905 and UPF-16), five introductions of A. fatua (I-93041, I-93033, I-93056, I-93058 and I-93066), five populations, $\mathrm{F}_{1}$ in 1994 and $\mathrm{F}_{2}$ in 1995 (I-93047, I-93048, I-93049, I-93052 and I-93069), and ten segregating populations $\mathrm{F}_{2}$ in 1994 and $\mathrm{F}_{3}$ in 1995 (I-93014, I-93027, I-93029, I-93034, I-93050, I-93060, I-93070, I-93072, I-93073 and I-93113), were used in this study.

The availability of genetic material in 1994 restricted the number of rows to two per genotype per block. The experiment was conducted in a randomized complete block design with two replications. In 1995, the cultivated, wild, $\mathrm{F}_{2}$, and $\mathrm{F}_{3}$ groups were placed in a single block, with five rows for both the cultivated and wild groups, and ten rows for both the $\mathrm{F}_{2}$ and $\mathrm{F}_{3}$ groups.

Evaluation of morpho-physiological traits were made for all the individual plants available. Plant height and flowering date were traits measured in both years.

The results were analyzed using analysis variance for each group and among them. Means comparison was made using Duncan's test at 5\% level for each group and among them.

\section{RESULTS AND DISCUSSION}

For plant height, significant differences were detected within each group in 1994 and 1995, pointing to broad genetic variability among the genotypes tested (Table 1). Three different classes for plant height were formed for cultivated groups in 1994, where UFRGS-91905 had the highest plant height, 
TABLE 1. Means for plant height $(\mathrm{cm})$ for genotypes within group and among groups of cultivated and wild oat, hybrids $F_{1}$ (1994) and $F_{2}(1995)$ and segregating $F_{2}(1994)$ and $\mathrm{F}_{3}$ (1995). Eldorado do Sul, RS, 1994/1995'.

\begin{tabular}{|c|c|c|c|}
\hline \multirow[t]{2}{*}{ Group } & \multirow[t]{2}{*}{ Genotype } & \multicolumn{2}{|c|}{ Plant height } \\
\hline & & 1994 & 1995 \\
\hline \multirow[t]{5}{*}{ Cultivated } & UFRGS-91905 & $88.81 \mathrm{~A}$ & $90.79 \mathrm{~B}$ \\
\hline & UFRGS-14 & 80.94B & $99.16 \mathrm{~A}$ \\
\hline & UPF-16 & $76.85 \mathrm{C}$ & $99.95 \mathrm{~A}$ \\
\hline & UFRGS-17 & $76.82 \mathrm{C}$ & $100.72 \mathrm{~A}$ \\
\hline & UFRGS-7 & $76.80 \mathrm{C}$ & $99.90 \mathrm{~A}$ \\
\hline Means & & $80.00 \mathrm{a}$ & $98.35 d$ \\
\hline C.V. $(\%)$ & & 4.24 & 6.29 \\
\hline \multirow[t]{5}{*}{ Wild } & I-93041 & $81.95 \mathrm{~A}$ & 124.12B \\
\hline & I-93066 & 81.00AB & $128.59 \mathrm{~A}$ \\
\hline & I-93058 & $80.81 \mathrm{AB}$ & $119.00 \mathrm{C}$ \\
\hline & I-93033 & $80.08 \mathrm{AB}$ & $124.02 \mathrm{~B}$ \\
\hline & $\mathrm{I}-93056$ & $77.29 \mathrm{~B}$ & 122.70BC \\
\hline Means & & $80.07 a$ & $123.78 \mathrm{c}$ \\
\hline C.V. (\%) & & 6.65 & 6.64 \\
\hline \multirow[t]{5}{*}{$\mathrm{F}_{1}$ and $\mathrm{F}_{2}$} & I-93049 & $84.60 \mathrm{~A}$ & $144.29 \mathrm{~A}$ \\
\hline & I-93048 & 81.50AB & $125.14 \mathrm{C}$ \\
\hline & I-93052 & 81.03B & 121.98D \\
\hline & I-93047 & 78.79BC & 129.10B \\
\hline & I-93069 & $76.40 \mathrm{C}$ & 121.44D \\
\hline Means & & $80.18 \mathrm{a}$ & $127.76 a$ \\
\hline C.V. $(\%)$ & & 7.69 & 7.76 \\
\hline \multirow[t]{10}{*}{$\mathrm{F}_{2}$ and $\mathrm{F}_{3}$} & I-93034 & $89.78 \mathrm{~A}$ & $115.60 \mathrm{E}$ \\
\hline & I-93072 & $85.96 \mathrm{~B}$ & $125.59 \mathrm{D}$ \\
\hline & I-93060 & $83.18 \mathrm{BC}$ & $133.32 \mathrm{C}$ \\
\hline & I-93073 & $82.54 \mathrm{BCD}$ & 127.89D \\
\hline & I-93029 & $82.46 \mathrm{BCD}$ & $135.21 \mathrm{BC}$ \\
\hline & I-93050 & 79.64CDE & $138.55 \mathrm{~B}$ \\
\hline & I-93014 & 79.36CDE & $143.12 \mathrm{~A}$ \\
\hline & I-93070 & $78.74 \mathrm{DE}$ & 127.15D \\
\hline & I-93027 & $76.44 \mathrm{EF}$ & $102.75 \mathrm{~F}$ \\
\hline & I-93113 & $72.75 \mathrm{~F}$ & $104.48 \mathrm{~F}$ \\
\hline Means & & $81.05 \mathrm{a}$ & $125.84 b$ \\
\hline Group-CV (\%) & & 7.09 & 8.78 \\
\hline C.V. $(\%)$ & & 8.12 & 9.68 \\
\hline
\end{tabular}

${ }^{1}$ Means followed by the same capital letter do not differ significantly by Duncan's test $5 \%$, among genotypes within the same group; mean followed by the same minuscule letter do not differ significantly by Duncan's test 5\%, among the groups within each year.

about $12 \mathrm{~cm}$ beyond the lowest genotype (UFRGS-7). In 1995, the analysis pointed to two distinct groups, where UFRGS-91905 showed the lowest plant height of the group. The mean for the cultivated group in 1995 was $18.35 \mathrm{~cm}$ beyond the mean of 1994 (Table 1).

Wild introductions of $A$. fatua $\mathrm{L}$. demonstrated in 1994 narrow amplitude of variation $(4.66 \mathrm{~cm})$ when compared to other groups. The introduction I-93041 showed the highest mean of the group, differing statistically only from I-93056. In 1995, the introductions were taller than 1994, about $43.71 \mathrm{~cm}$, while I-93058 revealed the lowest height of the group.

Two of the hybrid $F_{1}$ populations showed the highest plant height (I-93049 and I-93048). In 1995, the $\mathrm{I}-93049 \mathrm{~F}_{2}$ population was the tallest population. Mean for plant height in 1995 was $47.58 \mathrm{~cm}$ higher than in 1994 (Table 1).

Among the 10 segregating $\mathrm{F}_{2}$ populations in 1994 (Table 1), I-93034 showed the highest mean and the I-93113 the lowest mean, differing statistically from the remainder populations. In 1995 there was a modification in the behavior of segregating $\mathrm{F}_{3}$ populations, where I-93014 and I-93113 demonstrated the highest and lowest plant height among the groups, respectively.

The different oat groups analyzed in 1994 were not significantly distinct among them for plant height. In 1995, the lowest plant height was observed in the cultivated group, and the highest in segregating $\mathrm{F}_{2}$ and $F_{3}$ populations (Table 1).

For flowering date, estimated means for the cultivated group in 1994 showed distinct classes (Table 2). UFRGS-17 had the highest mean, 15.13 days beyond the earliest genotype of the group (UFRGS-91905). In 1995, results pointed to a reversion of the genotype values, when compared to 1994. UFGRS-91905 had the highest mean, 10.81 days later than UFRGS-17, the earliest of the group. Cultivated genotypes had increased 17.05 days in the means of the two years (Table 2).

Three different classes were observed for wild introductions in 1994 (Table 2), where I-93041 had the lowest value for flowering date, 19.18 days earlier than the later introduction (I-93066). In 1995, the ranking of the genotypes for this trait was modified, I-93058 was the earliest and I-93066, I-93033, I-93041 the latest in the group. Results also pointed out reduced variation among introductions, when compared to 1994.

For hybrid $F_{1}$ populations, two distinct classes were formed for flowering date in 1994 (Table 2), where the I-93048 population had the lowest mean for this trait, with 12.12 days earlier than the late population I-93049. In 1995, the same ranking was obtained for 
TABLE 2. Means for flowering date (days) for genotypes within group and among groups of cultivated and wild oat, hybrids $F_{1}(1994)$ and $F_{2}(1995)$ and segregating $F_{2}(1994)$ and $F_{3}$ (1995). Eldorado do Sul/ RS, 1994/19951.

\begin{tabular}{|c|c|c|c|}
\hline \multirow[t]{2}{*}{ Group } & \multirow[t]{2}{*}{ Genotype } & \multicolumn{2}{|c|}{ Flowering date } \\
\hline & & 1994 & 1995 \\
\hline \multirow[t]{5}{*}{ Cultivated } & UFRGS-17 & $82.50 \mathrm{~A}$ & 87.19D \\
\hline & UPF-16 & $76.73 \mathrm{~B}$ & $89.97 \mathrm{C}$ \\
\hline & UFRGS-14 & $74.69 \mathrm{BC}$ & $95.32 \mathrm{~B}$ \\
\hline & UFRGS-7 & $71.80 \mathrm{C}$ & $90.20 \mathrm{C}$ \\
\hline & UFRGS-91905 & 67.37D & $98.00 \mathrm{~A}$ \\
\hline Means & & $74.78 \mathrm{c}$ & $91.83 b$ \\
\hline C.V. $(\%)$ & & 9.73 & 3.17 \\
\hline \multirow[t]{5}{*}{$\overline{\text { Wild }}$} & I-93066 & $100.75 \mathrm{~A}$ & $89.00 \mathrm{~A}$ \\
\hline & I-93058 & $97.37 \mathrm{AB}$ & $81.31 \mathrm{C}$ \\
\hline & I-93033 & $95.00 \mathrm{AB}$ & $89.00 \mathrm{~A}$ \\
\hline & I-93056 & $89.58 \mathrm{BC}$ & $85.70 \mathrm{~B}$ \\
\hline & I-93041 & $81.57 \mathrm{C}$ & $88.57 \mathrm{~A}$ \\
\hline Means & & $91.83 b$ & $86.89 \mathrm{~d}$ \\
\hline C.V. $(\%)$ & & 12.73 & 4.91 \\
\hline \multirow[t]{5}{*}{$\overline{F_{1}}$ and $F_{2}$} & I-93049 & $97.44 \mathrm{~A}$ & $97.93 \mathrm{~A}$ \\
\hline & I-93047 & $93.70 \mathrm{~A}$ & $95.55 \mathrm{~B}$ \\
\hline & I-93069 & $87.74 \mathrm{~B}$ & $94.24 \mathrm{C}$ \\
\hline & I-93052 & 86.93B & $92.10 \mathrm{C}$ \\
\hline & I-93048 & $85.32 \mathrm{~B}$ & $94.75 \mathrm{~B}$ \\
\hline Means & & $89.93 b$ & $94.24 \mathrm{a}$ \\
\hline C.V. $(\%)$ & & 12.58 & 4.70 \\
\hline \multirow[t]{10}{*}{$\mathrm{F}_{2}$ and $\mathrm{F}_{3}$} & I-93073 & $108.04 \mathrm{~A}$ & $95.19 \mathrm{AB}$ \\
\hline & I-93070 & $106.22 \mathrm{~A}$ & $88.11 \mathrm{C}$ \\
\hline & I-93060 & $104.46 \mathrm{~A}$ & $88.59 \mathrm{C}$ \\
\hline & I-93029 & $104.00 \mathrm{~A}$ & $87.08 \mathrm{C}$ \\
\hline & I-93014 & $103.50 \mathrm{~A}$ & 93.19B \\
\hline & I-93050 & $99.64 \mathrm{AB}$ & $87.23 \mathrm{C}$ \\
\hline & I-93072 & $92.32 \mathrm{BC}$ & $93.86 \mathrm{AB}$ \\
\hline & I-93034 & 89.30CD & $95.94 \mathrm{~A}$ \\
\hline & I-93027 & $82.02 \mathrm{DE}$ & 83.92D \\
\hline & I-93113 & $78.19 \mathrm{E}$ & $82.70 \mathrm{D}$ \\
\hline Means & & $95.77 \mathrm{a}$ & $89.60 c$ \\
\hline Group-C.V. (\%) & & 13.21 & 6.98 \\
\hline C.V. $(\%)$ & & 14.58 & 8.57 \\
\hline
\end{tabular}

${ }^{1}$ Means followed by the same capital letter do not differ significantly by Duncan's test $5 \%$, among genotypes within the same group; means followed by the same minuscule letter do not differ significantly by Duncan's test 5\%, among the groups within each year.

$F_{2}$ populations, except to I-93047 population which demonstrated an intermediate classification. An enhancement for flowering date was observed through the means of the groups obtained from 1994 and 1995.

Segregating $\mathrm{F}_{2}$ populations showed broad genetic variability for flowering date. I-93113 population had the lowest mean for this trait, 29.85 days earlier than I-93073, the late population of the group. In 1995, segregating $\mathrm{F}_{3}$ population, I-93113 and I-93027 had maintained the ranking of 1994, with 13.24 and 12.02 days earlier than I-93034, the late population.

The intermediate similar behavior of plant height among oat groups in 1994 and the modified ranking of the genotypes from 1994 to 1995 within groups may be explained by environment influence. Great genetic variability was detected within and among the studied groups, with the lowest plant height from cultivated groups explained by strong selection pressure made by breeding programs for reduction of this trait. Carvalho \& Federizzi (1989) suggested that advances in yield of oat were obtained through adjusted selection procedures to the Southern Brazilian environment conditions, primarily plant height reduction, earliness and fertility enhancement (grains/panicle). On the other hand, wild introductions of $A$. fatua showed tall plants, probably because of absence of artificial selection for this group or absence of genes for reduced plant height in the studied group. Luby \& Stuthman (1983), when evaluating wild introductions of $A$. fatua for agronomic traits had also found genotypes taller than cultivated genotypes. Plant height in the A. fatua group is an important source of maintenance and surviving for wild races, since higher plants are benefited in environment competition. These results agree with those from Pfeifer \& Carvalho (1981), who demonstrated that tall wheat genotypes exercise strong competition over plants with reduced height, leading to a progressive elimination of short individuals, when artificial selection is absent.

Although the intermediate plant height of segregating $\mathrm{F}_{3}$ populations in 1995 had been higher than the cultivated group, some of these populations (I-93113, I-93027 and I-93034) present short plants which can be explained by genetic recombination between parents of these populations, resulting in a decreasing of plant height, facilitating its utilization in breeding programs.

For number of days to flowering, a narrow variation within groups was osbserved. The distribution of frequency pointed out that wild 
introductions of $A$. fatua evaluated had most of the plants with the lowest number of days to flowering. The introduction I-93058 was the earliest among genotypes, probably because the reduced number of leaves, which can be considered as a strong source of genes for earliness. For wheat, Wobeto (1994) also observed that reduced number of days to flowering in BR 35 was related to low necessity of heat unit, reduced filocron and higher index of leaves emergence. For oat, Suneson (1967) transferred earliness and fast development from wild introductions of A. fatua to Rapida cultivar. For segregating $\mathrm{F}_{2}$ populations, none presented earliness for flowering date, probably because of the genetic similarity between parents which originated those populations or the absence of enough recombination for expression of earliness. Nevertheless, $\mathrm{F}_{3}$ populations- I-93113 and I-93027 showed high frequency of early plants, which may be selected and included to further agronomic evaluations.

The intermediate similar behavior for flowering date pointed that some of the wild introductions of A. fatua had genes for earliness, as well as some of the segregating $\mathrm{F}_{3}$ populations (I-93113 and I-93027) which showed similar means within the group and differences among cultivated groups and segregating $\mathrm{F}_{2}$ populations. These results differ from that obtained from Tavares (1991) when evaluated A. sterilis introductions and cultivated oat genotypes, where the first showed superiority for flowering date in relation to the cultivated group.

Oat wild races (A. fatua and A. sterilis ) are closely related to the cultivated group and seems to be a potential source of genes helpful to plant breeding. Our results about morpho-physiological traits on wild introductions and natural segregating populations of A. fatua x A. sativa demonstrated genetic variability within and among the evaluated groups. As a consequence, the maintenance of related wild genotypes is important for conservation and transference of genes of agronomic importance into cultivated germ plasm, assuring genetic diversity in the germ plasms, allowing the breeder to select genotypes with high grain yield and adaptive traits (plant height and flowering date) desirable to conditions of the Southern Brazil.

\section{CONCLUSIONS}

1. The groups evaluated result in broad genetic variability within and among groups for both morphophysiological traits.

2. Wild introductions of Avena fatua L. present tall plants and reduced flowering date.

3. The populations I-93027 and I-93113 show genotypic combination of reduced plant height and earliness.

\section{REFERENCES}

BERTAGNOLLI, P.F. Análise genética de caracteres adaptativos em aveia (Avena sativa $\mathbf{L}$.). Porto Alegre: UFRGS, 1992. 112p. Tese de Doutorado.

BRIGGLE, L.W.; VOGEL, O.A. Breeding short-stature, disease resistant wheats in the United States. Euphytica, Wageningen, v.17, p.107-130, 1968.

CARVALHO, F.I.F.; FEDERIZZI, L.C. Evolução da cultura de aveia no Sul do Brasil. Trigo e Soja, Porto Alegre, v.102, p.16-19, 1989.

DERICK, R.A. Natural crossing with wild oats, Avena fatua. Science in Agriculture, Pennsylvania, v.13, p.458-459, 1933.

DILLENBURG, C.R. Identificação das espécies do gênero Avena (Gramineae) coletadas no Estado do Rio Grande do Sul (Brasil). Anuário Técnico do Instituto de Pesquisas Zootécnicas 'Francisco Osório’, Porto Alegre, v.11, p.65-102, 1984.

FEDERIZZI, L.C.; QUALSET, C.O. Genetics of plant height reduction and panicle type in oat. Crop Science, Madison, v.29, p.551-557, 1989.

LUBY, J.J.; STUTHMAN, D.D. Evaluation of Avena sativa L. I Avena fatua L. progenies for agronomic and grain quality characters. Crop Science, Madison, v.23, p.1047-1052, 1983.

PFEIFER, A.B.; CARVALHO, F.I.F. Análise da competição intergenotípica sob efeitos de seleção natural e artificial em populações de trigo (Triticum aestivum L.). Agronomia Sulriograndense, Porto Alegre, v.17, n.1, p.3-23, 1981.

Pesq. agropec. bras., Brasília, v.34, n.8, p.1393-1398, ago. 1999 
SUNESON, C.A. Registration of 'Rapida' oats. Crop Science, Madison, v.7, p.168, 1967.

TAVARES, M.J.C.M. S. Variabilidade genética em Avena sativa L., Avena sterilis L. e em seus híbridos: avaliações agronômicas, morfológicas, citogenéticas e eletroforéticas. Porto Alegre: Depar- tamento de Genética, UFRGS, 1991. 141p. Tese de Doutorado.

WOBETO, C. Padrão de afilhamento, sobrevivência de afilhos e suas relações com o rendimento de grãos em trigo. Porto Alegre: UFRGS, 1994. 102p. Dissertação de Mestrado. 